\title{
OCTAVIO PAZ COMO CRÍTICO DE ARTE: LA VISIÓN LÚDICAY CONTEMPLATIVA DEL MUNDO
}

\section{Octavio Paz as an art critic: the playful and contemplative vision of the world}

\author{
Basilio Belliard \\ Universidad Autónoma de Santo Domingo (UASD), República Dominicana. Correo-e: basiliobelliard3@gmail.com \\ https://orcid.org/0000-0002-7848-4055
}

Recibido: 2/4/2019 • Aprobado: 8/5/2019

Cómo citar: Belliard, B. (2019). Octavio Paz como crítico de arte: la visión lúdica y contemplativa del mundo. Ciencia y Sociedad, 44(2), 81-85. Doi: https://doi.org/10.22206/cys.2019.v44i2.pp81-85



En su magna obra, Los privilegios de la vista (título gongorino), el poeta mexicano y Premio Nobel Octavio Paz (1914-1998) reúne sus ensayos sobre el arte de México, desde el arte prehispánico hasta el arte moderno, los muralistas mexicanos -Orozco, Diego Rivera y Siqueiros- y otros artistas como Rufino Tamayo, José Guadalupe Posada, Armando Álvarez Bravo, Remedios Varo, Juan Soriano, Pedro Coronel, José Luis Cuevas, Gerzso, entre otros. Además, escribió luminosas y lúcidas páginas sobre otros artistas visuales y universales, como Picasso, Chillida; o el grabado latinoamericano y la pintura norteamericana hasta su consagración, tras escribir una monografía sobre Marcel Duchamps, titulada Apariencia desnuda: la obra de Marcel Duchamps. Esta obra es un análisis reflexivo acerca de los cuadros El gran vidrio y Ensamblaje, así como una introducción a la obra pictórica de este desconcertante artista dadaísta francés, creador del ready made o instalación. Se trata de un estudio donde Paz intenta revelar la filiación de la pintura de Duchamps con la metaironía, insertada en la tradición occidental de la modernidad. Valga decir 
que las reflexiones iniciales de Paz aparecen en la segunda edición de la obra titulada Marcel Duchamps o el castillo de la pureza.

Octavio Paz, como discípulo y luego amigo de André Breton, fue un compañero de viaje de los pintores surrealistas franceses. Esta experiencia fue vital en su oficio de crítico de arte, como poeta que cultivó no la "escritura automática", sino que orilló en vertientes imaginarias, lúdicas y creativas, en dos libros de poemas en prosa como ¿'Águila o sol? o el Mono gramático. De modo pues que Paz siempre merodeó y buceó en las aguas de la ensoñación y la fantasía onírica, desde sus primeros contactos con los poetas surrealistas y dadaístas en Francia, a finales de los años cuarenta y cincuenta.

Podría decirse que el primer impulso -o el despertar- de su vocación como crítico de arte le nació desde muy joven, cuando visitó por primera vez Estados Unidos, como secretario de la Embajada de México, donde tuvo la oportunidad de visitar el Museo de Arte Moderno y el Metropolitan Museum de Nueva York. De esas visitas acaso brotó la pasión por la pintura y las artes visuales, concomitantemente con su vocación poética, pues ya era un poeta de libros publicados.

Octavio Paz es un poeta que asumió la crítica de arte como un género literario -como lo hizo con el poema, la traducción, el ensayo, la entrevista o la carta-. Su experiencia crítica se define como una traducción al lenguaje literario del lenguaje visual. Sus páginas de críticas se leen como creaciones verbales, inspiradas o insufladas por el color, las líneas y la composición plástica. Funda un discurso verbal a partir de la contemplación y la mirada crítica de un cuadro. Crea así un discurso paralelo entre la palabra y el cuadro, la imagen visual y la poesía: va pues de la pintura a la poesía y de esta a aquella. Postula, en efecto, una correspondencia íntima entre el cuadro pictórico y la mirada poética. Entre el ojo y la palabra poética brota la crítica, que resulta del matrimonio entre el pintor y el poeta.
Paz no es el pintor-poeta -como Juan Ramón Jiménez, Henri Michaux, William Blake, José Hierro, Rafael Alberti, entre otros-, sino el poeta-crítico (como Baudelaire) que, sin la formación académica del historiador del arte o del crítico de arte, desarrolló una obra o una trayectoria como crítico de arte sorprendente y visionaria, en cuyas páginas reverberan la gracia, el encantamiento y la revelación.

Su obra crítica en artes visuales, expresada en artículos, conferencias, ensayos y textos para catálogos, se encuentra dispersa en libros como Las peras del olmo, El signo y el garabato, Sombras de obras, Puertas al campo, In-mediaciones, Convergencias y Corriente alterna, donde figuran sus primeras reflexiones filosóficas y teóricas sobre el arte, la abstracción, el surrealismo y las vanguardias, en fragmentos y breves ensayos.

Resulta asombrosa la capacidad de Paz para ver con los ojos de la poesía, las imágenes visuales de la pintura y la escultura, para auscultar y penetrar en el universo de los cuadros y los objetos artísticos; también, para descubrir y descubrirnos los mundos figurativos y abstractos de pintores, de lenguajes imaginarios y técnicas disímiles.

Para el autor de Corriente alterna, la crítica de arte y de literatura es un ejercicio de pensamiento, una práctica del intelecto, que concibió con vocación apasionada, es decir, con pasión y penetración crítica. Para él, la crítica tiene que ser imaginativa y la imaginación, por su parte, crítica. A propósito de Rufino Tamayo, Paz, en su obra Puertas al campo, define su arte y su poética de la crítica de arte así: "La crítica no solo hace más intenso y lúcido mi placer, sino que me obliga a cambiar mi actitud ante la obra. Ya no es un objeto, una cosa, algo que acepto o rechazo y sobre lo cual, sin riesgo para mí, dejo caer una sentencia. La obra ya forma parte de mí y juzgarla es juzgarme. Mi contemplación ha dejado de ser pasiva: repito, en sentido inverso, los gestos del artista, marcho hacia atrás, hacia el 
origen de la obra y a tientas, con torpeza, rehago el camino del creador. El placer se vuelve creación. La crítica es imitación creadora, reproducción de la obra... La crítica no es tanto la traducción en palabras de una obra como la descripción de una experiencia" (Paz, 1989, pp. 173-174). Con estas lúcidas palabras, Paz define su concepto de la crítica y de la obra de arte, así como de su teoría estética del arte.

El autor de Las peras del olmo hizo pues una obra crítica, a partir de su sensibilidad, su imaginación y su experiencia visual, al contacto con pintores y en diálogo productivo y contemplativo entre la pintura y la poesía. Si pintar para él es aprender a ver con los ojos, esta experiencia es un "privilegio de la vista” y también una fiesta de la contemplación. $\mathrm{Si}$ se aprende de esta experiencia estética es porque no solo hay imágenes, sino también pensamiento $y$, por tanto, conocimiento. También, Paz quería que los demás vieran lo que él veía y que sintieran lo que él sentía desde su experiencia visual. Entabló así un diálogo visual y verbal entre lo mirado y lo leído, pues ver es también leer: un cuadro se lee como se lee un libro -de ahí que Omar Calabrese titule su libro Cómo mirar un cuadro-. El crítico es pues un intermediario entre el cuadro o la obra y el público. Y Paz se transforma, con su sensibilidad poética, en un médium, cuando traduce, con su mirada, lo visto y entrevisto, para volverlo a traducir en palabras, que brotan del mismo acto de contemplación primera. Pero, la crítica que escribió Paz está dirigida a la cabeza, es decir, a la mente sensible. De suerte que su crítica nos hace pensar: nos insta a pensar y nos ayuda a descifrar los signos, los códigos y los símbolos que constituyen la composición pictórica. Más bien, sus páginas críticas nos sacuden la conciencia estética: nos despiertan la vocación y el amor por las obras de artes visuales.

Resulta curioso que, siendo Octavio Paz un poeta y ensayista, haya contribuido a la renovación y transformación del modo de mirar y hacer crítica de arte en nuestra lengua y en nuestra tradición crítica, tanto en América Latina como en el mundo hispánico.
Es una crítica con vocación de estilo y hecha desde la contemplación y el pensamiento, la reflexión y la mirada lúdica. Sus páginas se leen como poemas en prosa, o sea, a lo que aspiraba Charles Baudelaire que debía ser la verdadera crítica de arte. De ahí que los mejores críticos de arte son los poetas. No es casual que haya sido Apollinaire quien descubriera a los pintores cubistas, acuñado este nombre y que haya sido André Breton el primer gran teórico y crítico de los pintores surrealistas. O que fuera el poeta y escritor guatemalteco-mexicano Luis Cardoza y Aragón uno de los más agudos críticos de arte de latinoamérica.

La esencia de la crítica de arte paciana no reside en el desciframiento de líneas y colores, sino en ver los cuadros como fuentes de ideas y como pretexto para pensar y elucubrar; es decir, la pintura como representación simbólica del espacio y plasmación de los colores del mundo. Nos ayuda a descifrar los lenguajes de la pintura, donde el cuadro encarna la imagen de la naturaleza, que funciona a la vez como traducción del universo. Así pues, la crítica de arte se vuelve la traducción verbal de una experiencia visual empírica. La búsqueda de formas visuales en los pintores condujo a Paz a hacer reflexiones sobre el arte de pintar, o sea, la contemplación de cuadros le sirvió de pretexto para elaborar sus teorías sobre la pintura como arte y de los cuadros como obras de arte. En consecuencia, pasa de la mirada crítica a la reflexión teórica del arte, de la crítica de la obra de arte y del objeto artístico a la teoría crítica del arte moderno y contemporáneo. Para este poeta mexicano, la crítica no solo se funda en el juicio o el análisis, sino que es un acto de creación, vale decir, un producto de la imaginación. En efecto, hizo de la crítica una profesión de fe, una vocación apasionada y constante, un ejercicio de la imaginación, pero insuflada por el espíritu de la poesía. Por consiguiente, el diálogo entre el tacto y la vista es esencial para la sensibilidad del crítico de arte.

En sus críticas de arte visual hay una correspondencia entre el ojo y el oído, a la manera como concibió Étienne Souriau la correspondencia entre las artes 
temporales y las espaciales, o como Kandinsky vislumbró lo espiritual en el arte, hallando música en el color -"El azul es una sinfonía", dijo-; o Rimbaud, que vio colores en las vocales. Es decir que, para Paz, al ver un cuadro, oímos con los ojos, y al oír, vemos con los oídos. Esta idea será obsesiva en él con relación a la pintura y de ahí la vinculación entrañable que postula su aproximación crítica al cuadro. Al hacer la crítica, nos transmite su percepción de la obra de arte visual y nos la devuelve, convertida en texto verbal: del texto visual al texto literario. Su estilo de hacer crítica de arte es una herencia simbolista que lo consagró y enriqueció con el surrealismo, al contacto con André Breton y los demás pintores surrealistas de espíritu poético, o de los poetas surrealistas de espíritu pictórico.

Romper los límites entre las artes visuales y la poesía, y convertir el ensayo literario en vehículo para escribir crítica de arte, con proverbial y ejemplar eficacia y lucidez, hizo de este poeta y ensayista un paradigma dentro de la escasa tradición de poetas-críticos de arte. De modo pues que esta faceta ocupa un espacio de especial valor en el universo de su obra en prosa ensayística y un lugar señero en el concierto del orbe latinoamericano. Cada página y cada texto de crítica de arte tiene en Paz un aura de esplendidez, pues ausculta y penetra en resquicios y espacios de cuadros y formas artísticas, desde su experiencia poética, donde no llega el novelista, ni el filósofo, ni el crítico de arte a secas. Acaso porque este poeta poseía la sensibilidad, el espíritu estético y la cultura visual que le permitieron ahondar en las profundidades de las composiciones pictóricas, tal como un pez en el agua.

Así pues, Paz vio con ojos de poetas, pinturas y cuadros, esculturas y objetos de arte; de ahí que su crítica tiene la forma sensible y la expresión lúdica de su estilo, al enunciar y argumentar sobre las composiciones plásticas. Y en ese vaivén, entre la imagen visual percibida y la palabra crítica, vista desde la perspectiva de su ojo interior, opera su temperamento crítico y su estilo de captar y visualizar los colores y las formas del cuadro. Dice Paz, en tal sentido: "Poesía y pintura son artes que se despliegan en territorios opuestos: el reino de la poesía es el tiempo y el de la pintura el espacio; la poesía se oye y la pintura se contempla: el poema transcurre y al transcurrir cambia mientras que el cuadro siempre es idéntico a sí mismo. Sin embargo, la facultad que rige a pintura y poesía es una; aunque el pintor se sirve de los ojos y el poeta de la lengua, ojos y lengua obedecen a la misma potencia: la imaginación" (Paz, 1991, p. 36).

Entonces, Paz concibe el cuadro como una metáfora poética, más allá de ser una simple composición plástica; es decir, que el cuadro actúa como un espejo que refleja la imagen visual en la mirada verbal. De suerte que el cuadro pictórico participa, en su imaginario, como un poema hecho no de palabras, sino de imágenes plásticas. En efecto, el cuadro visual se transfigura en un tejido -o textohecho de colores, formas y líneas armónicas, sonoras y rítmicas que se abstraen y se hacen visibles al espectador. Entre estos elementos compositivos hay ritmos y rimas no verbales, sino visuales. Paz se apropia de ellos para articular su discurso crítico frente al cuadro, contemplado por su mirada de poeta sensible. Para este ensayista, el color es la voz de la pintura, de ahí que nos inste no solo a ver un cuadro simplemente, sino a leerlo con los ojos de la razón y a oírlo con los oídos de la pasión; por eso nos invita siempre a ver y oír la pintura, simultáneamente. De tal modo, escribe lo que percibe y siente al contemplar el cuadro y plasma sus ideas a partir de la reflexión que le depara su experiencia visual del instante de la mirada crítica. Así, sus críticas devienen poetizaciones, producto del hechizo de su mirada, al contemplar el texto visual. Más bien, sus escritos críticos son prolongaciones de su estado de percepción de la obra de arte plástica.

En síntesis, Paz ve los cuadros con los ojos de su espíritu poético. Destruye las fronteras entre la crítica y la creación, de modo que sus críticas de arte son creativas, o sea, creaciones literarias o poemas en 
prosa -poemas, relatos en prosa poética-; y así se confunden y superponen crítica y creación verbal (el poema y la crítica). En suma, el ensayo paciano de crítica de arte oscila entre la creación y el pensamiento, y la poesía que le sirve de eje de mediación.

\section{Bibliografía}

Paz, O. (1992). "Presencia y presente: Baudelaire crítico de arte”. En El signo y el garabato.México DF: Joaquín Mortiz, p. 36-54

Paz, O. (1989). “Tamayo: transfiguraciones": Puertas al campo. Barcelona, España: Seix Barral.

Paz, O. (1987). Los privilegios de la vista: Arte de México. Ciudad de México: FCG.
Paz, O. (1984). Las peras del olmo. Barcelona, España: Seix Barral.

Paz, O.(1983). Sombras de obras: Arte y literatura. Barcelona, España: Seix Barral.

Paz, O. (1991). Convergencias. Barcelona, España: Seix Barral.

Paz, O. (1990). Corriente alterna. Ciudad de México, Siglo XXI Editores.

Paz, O. (1989). Apariencia desnuda: la obra de Marcel Duchamps. Barcelona, España: Alianza FormaERA, Alianza Editorial.

Paz, O. (1979). In-mediaciones. Barcelona, España: Seix Barral.

\section{Datos de filiación}

Basilio Belliard. Ensayista, poeta y crítico literario dominicano. Es doctor en filosofía por la Universidad del País Vasco. Es miembro correspondiente de la Academia Dominicana de la Lengua y Premio Nacional de Poesía Salomé Ureña. Fue profesor invitado por la Universidad de Orleans, Francia, y teaching asistant en New Mexico State Universidad. Es profesor de las facultades de Artes y de Humanidades de la Universidad Autónoma de Santo Domingo, desde hace más de dos décadas. Textos suyos han sido traducidos al francés y al italiano. Es autor de una decena de libros de ensayos, poesías, antologías, aforismos y microrrelatos. 